\title{
Dietary conjugated linoleic acid isomers and selenium affect the fatty acid profile in rat liver*
}

\author{
M. Czauderna ${ }^{1}$, J. Kowalczyk, K. Korniluk, I. Wąsowska \\ and B. Pastuszewska
}

The Kielanowski Institute of Animal Physiology and Nutrition, Polish Academy of Sciences 05-110 Jabtonna, Poland

\begin{abstract}
The influence of dietary conjugated linoleic acid (CLA) isomers and/or $\mathrm{Se}\left(\mathrm{as}_{2} \mathrm{Se}_{4}\right)$ on the content of CLA isomers and other fatty acids (FAs) in rat liver was investigated. Feeding CLA isomers resulted in an elevated hepatic CLA isomer content. The diet with Se and cis9trans11 CLA most effectively elevated the liver content of cis 9 trans 11 , cis,tras/trans, cis, the sum of CLA isomers, C20:4 and C20:6. Adding Se, cis9trans11CLA or a CLA isomer mixture decreased the capacity of $\Delta 6-, \Delta 5$-desaturases and elongase, while trans10cis 12 had the opposite effect. Feeding $\mathrm{Se}$ or CLA isomers reduced $\Delta 9$-desaturase capacity.
\end{abstract}

KEY WORDS: CLA isomers, fatty acids, rats, liver, GLC, HPLC

\section{INTRODUCTION}

Numerous investigations have demonstrated that CLA isomers alter lipid metabolism in the liver and adipose tissue. Indeed, PUFA have been shown to decrease SREBP-1 mRNA $^{2}$ in liver, therefore leading to reduced lipogenic gene expression. Moreover, in some studies it has been reported that dietary CLA isomers can modify the oxidation of fatty acids (FAs).

Therefore, the aim of this study was to investigate the CLA isomer profile and composition of other FAs in the liver of rats fed a mixture of CLA isomers: cis 9 , trans $11(c 9, t 11)$, trans10, cis12 $(t 10, c 12)$ and/or 2 ppm $\mathrm{Se}\left(\operatorname{as~}_{2} \mathrm{Na}_{2} \mathrm{SeO}_{4}\right)$.

\footnotetext{
* Supported in part by the State Committee for Scientific Research, Grant No. 3 PO6Z 03422

${ }^{1}$ Corresponding author: e-mail: m.czauderna@ifzz.pan.pl

${ }^{2}$ sterol regulatory element binding proteins (SREBP) mRNA (type of SREBP: SREBP-1a, $-1 \mathrm{~b}$ and $-1 \mathrm{c}$ )
} 


\section{MATERIAL AND METHODS}

Ten groups of 7-8 female rats each (Wistar, Ifz: BOA), 8 weeks of age and an initial body mass $\sim 200 \mathrm{~g}$ were housed individually as described previously (Czauderna et al., 2004). Rats were fed the Labofeed diet or one enriched in 1-2\% CLA isomers, 2 ppm Se (as $\mathrm{Na}_{2} \mathrm{SeO}_{4}$ ) (Table 1), ad libitum. After 28 days the rats were killed by $\mathrm{CO}_{2}$ and their livers were removed and freeze-dried.

All reagents used and the saponification methylation methods were as previously described (Czauderna et al., 2005). CLA isomers and other FAs containing conjugated double bonds (CFA) were determined using ion $(\mathrm{Ag}+)$ liquid chromatography $\left(\mathrm{Ag}^{+}-\mathrm{HPLC}\right)$, while analysis of all FAs in rat liver was carried out using GLC (Czauderna et al., 2005).

The effects of CLA isomers or Se treatments were subjected to statistical analysis using the nonparametric Mann-Whitney U test, while the simultaneous Se and CLA treatment was analysed by two-factorial analysis. Statistica (ver. 6) and Excel 2000 were used.

\section{RESULTS AND DISCUSSION}

No lesions or symptoms of harmful effects of Se were found in rats fed diets with Se. The FA composition in rat liver was altered by the treatment with CLA isomers and/or Se (Table 1). Incorporation of isomers $c 9 t 11$ and $t 10 c 12$ and $t, t$ was found to be selective; in particular, the percentage contribution of t,t isomers in liver was relatively higher compared with their share $(\sim 15 \%)$ in the dietary CLA isomer mixture. The $t, t$ isomers are catabolized more slowly and are poor species for $\beta$-oxidation; they are more efficiently accumulated into liver membrane phospholipids due to their geometrical configuration. On the other hand, the percentage contribution of $c 9 t 11$ and t10c12 was lower than in the administered CLA isomer mixture and the content ratio of $t 10 c 12$ to $c 9 t 11$ in the liver was smaller than in the CLA isomer mixture. The $c 9 t 11$ and $c 11, t 13$ isomers were preferentially metabolized (like other $c, t / t, c$ isomers) to form CFA (i.e. C18:3, C20:3, C20:4), while $t 10 c 12$, $t 10 t 12$ and $t 8 c 10$ isomers were more efficiently driven through $\beta$-oxidation than their 9,11 homologues. Se most efficiently elevated the content of $c 9 t 11$ (285\%), c, t/t,c (286\%), the sum of CLA isomers (281\%), C20:4 and C20:6 in the liver of rats simultaneously fed Se and c9t11 CLA (positive interaction). Our recent study has also indicated that dietary Se increased the $c 6$ C18:1 content in the liver of rats fed Se and c9t11 or other CLA isomers, probably due to stimulation of $\Delta 6$-desaturase capacity (a positive interaction). These results suggest that dietary Se and isomer $c 9 t 11$ most efficiently stimulated the capacity of $\Delta 6-, \Delta 5$ desaturases and elongase; so feeding diet $8_{+\mathrm{Se}}$ increased the content of CFA, C20:4 and $\mathrm{C} 22: 6$ in the liver. This effect may be also attributed to the ability of dietary Se 


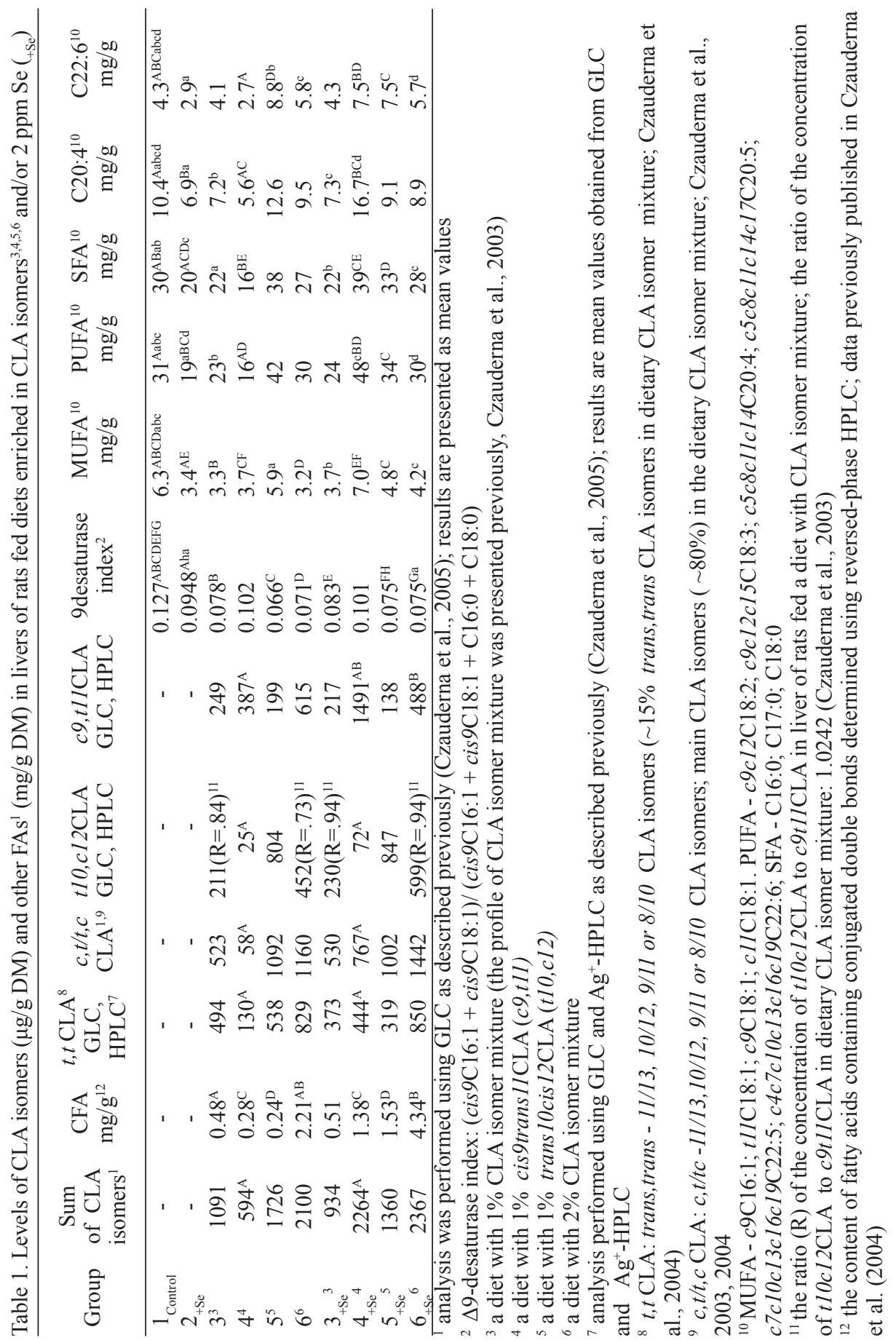


to diminish the efficiency of $\beta$-oxidation of administered CLA isomers, particularly c9t11CLA, as well as other non-CLA FAs in liver. These results suggest that Se, c9t11 or the CLA isomer mixture decreased the capacity of $\Delta 6-, \Delta 5$-desaturases and elongase $^{3}$ (negative interaction), while $t 10 \mathrm{cl} 2 \mathrm{CLA}$ increased the capacity of these enzymes. Feeding Se or CLA isomers probably caused reduction of $\Delta 9$-desaturase capacity (most effectively $t 10 c 12 \mathrm{CLA}$ regardless of Se presence), while Se in the diet with CLA isomers slightly stimulated the capacity of this enzyme (positive interaction). Consequently, the hepatic MUFA and PUFA contents of rats fed Se or CLA isomers numerically or statistically decreased, while extra Se in the diet with CLA isomers usually slightly elevated the content of MUFA in liver (positive interaction).

\section{CONCLUSIONS}

Our results indicate that CLA isomers (especially c9t11) decreased $\Delta 9-, \Delta 6$ and $\Delta 5$-desaturase capacity. Therefore, finding that CLA isomers, especially $c 9 t 11$, modify arachidonate metabolism with concurrent reduction of arachidonatederived eisosanoid biosynthesis (cancer stimulating metabolites) and increase the level of $c 9 t 11^{4}$ and other conjugated fatty acids in the animal body confirm the particular importance of our program of developing functional food by feeding domestic animals a diet enriched in CLA isomers.

\section{REFERENCES}

Czauderna M., Kowalczyk J., Korniluk K., Wąsowska I., 2005. Improving the analysis of fatty acids using combination of gas chromatography and $\mathrm{Ag}^{+}$liquid chromatography. J. Anim. Feed Sci. 14, Suppl. 1, 563-566

Czauderna M., Kowalczyk J., Niedźwiedzka K.M., Wąsowska I., Pastuszewska B., Bulska E., Ruszczyńska A., 2004. Liver and body mass gain, content of CLA isomers and other fatty acids in the liver of rats fed CLA isomers and selenium. J. Anim. Feed. Sci. 13, 353-369

Czauderna M., Kowalczyk J., Wąsowska I., Niedźwiedzka K.M., 2003. Determination of conjugated linoleic acid isomers by liquid chromatography and photodiode array detection. J. Anim. Feed Sci. $12,269-382$

\section{STRESZCZENIE}

\section{Wpływ izomerów CLA i Se w diecie na zawartość kwasów tluszczowych wątrobie szczurów}

Stwierdzono wzrost zawartości izomerów sprzężonego kwasu linolowego (CLA) w wątrobie szczurów żywionych dietą z dodatkiem izomerów CLA i/lub Se (w postaci $\mathrm{Na}_{2} \mathrm{SeO}_{4}$ ). Se, cis 9 trans 11CLA $i$ mieszanina izomerów CLA zmniejsza stężenie nasyconych i nienasyconych kwasów tłuszczowych oraz efektywność działania procesu $\Delta 9$-, $\Delta 6$ - i $\Delta$ 5-desaturacji.

\footnotetext{
${ }_{3 \text { probably } c 9 t 11}$ metabolites compete with C18:3n-3, C18:2n-6 metabolites for these enzymes

${ }^{4}$ having anti-carcinogenic properties
} 